\title{
ENERGY CONSUMPTION OF YAM SLICE DRYING IN AN EXHAUST GAS WASTE HEAT RECOVERY HOT AIR TRAY DRYER
}

\author{
Chibuike Ononogbo * \\ Department of Mechanical Engineering Technology \\ Imo State Polytechnic, Umuagwo, P.M.B 1472 Owerri, Imo State, Nigeria. \\ Email: mariapeter2001@ gmail.com \\ Dr. Olisaemeka Chukwudozie Nwufo \\ Department of Mechanical Engineering \\ Federal University of Technology, Owerri, Imo State, Nigeria \\ Email: ufodugaa@yahoo.com \\ Dr. Nnaemeka Reginald Nwakuba \\ Department of Agricultural and Bioresources Engineering \\ Federal University of Technology, Owerri, Imo State, Nigeria \\ Email: nrnwakuba@gmail.com \\ Dr. Chukwunenye Anthony Okoronkwo \\ Department of Mechanical Engineering \\ Federal University of Technology, Owerri, Imo State, Nigeria \\ Email: Chukwunenye_jireh@yahoo.com \\ Dr. Johnson Onyechege Igbokwe \\ Department of Mechanical Engineering \\ Federal University of Technology Owerri, Imo State Nigeria \\ Email: johnkwe678@yahoo.com \\ Professor Emmanuel Enyioma Anyanwu \\ Department of Mechanical Engineering \\ Federal University of Technology, P.M.B. 1526 Owerri, Imo State Nigeria \\ Email: eemmanuelanyanwu@ gmail.com \\ Phone no.:+2348036718970 \\ *Corresponding Author: Email: mariapeter2001@ gmail.com
}

\begin{abstract}
Evaluation of the energy consumption during the thin-layer drying of yam slices in an exhaust gas waste heat recovery dryer is presented. The study took cognizance of some energy parameters such as the electric power consumption, thermal energy consumption and specific energy consumption during the drying process. Blanched white yam samples of different thicknesses were subjected to varying conditions of drying air temperatures and velocities of 55, 65, and $75^{\circ} \mathrm{C}$; and $1.0,1.5$, and $2.0 \mathrm{~m} / \mathrm{s}$. The minimum value of electric power consumption ( $44.63 \mathrm{~W}-\mathrm{hr}$ ) was achieved at the drying air temperature and velocity of $75{ }^{\circ} \mathrm{C}$ and $1.0 \mathrm{~m} / \mathrm{s}$, and slice thickness of $1.0 \mathrm{~cm}$; whereas a maximum value of $157.70 \mathrm{~W}$-hr was obtained at the drying air temperature and velocity of $55^{\circ} \mathrm{C}, 2.0 \mathrm{~m} / \mathrm{s}$, and $1.0 \mathrm{~cm}$ slice thickness, respectively. The specific energy consumption values were in the range of 40.25 to $97.80,52.33$ to 108.79 and 58.77 to 124.16 $\mathrm{kW}-\mathrm{hr} / \mathrm{kg}$, respectively for $1.0,1.5$ and $2.0 \mathrm{~cm}$ slice thicknesses. The results obtained revealed that the drying air temperature and velocity had an appreciable influence on the values of the energy consumption
\end{abstract}

parameters of the dryer for the yam slice drying. It was observed that for all the experimental treatments, the higher the slice thickness of the yam samples, the higher the obtained energy consumption values.

Keywords: slice thickness, energy consumption, drying, waste heat recovery, yam

\section{INTRODUCTION}

White yam (Dioscorea rotundata) is an important food crop in many tropical regions because it contains some essential nutrients such as starch, protein, vitamin $\mathrm{C}$ and some minerals. It is a food security crop that is considered healthy and economical. They are root crops indigenous to West Africa $[1,2]$. Raw yam is a perishable crop as a result of its high moisture content of about $69.6 \%$ [2]. It is widely applied in Orthodox Chinese medicine because it possesses some 
substances that inhibit the formation of the fungi that cause cancer and thrombosis [3, 4]. Statistics show that more than $20 \%$ of yam tubers perish during postharvest periods, thus affecting the income and profit margin of both the farmers and traders $[5,6]$. Therefore, yam is not expected to be stored for not more than a few weeks after its harvest; and should be subjected to drying to preserve its quality all year round. The huge losses experienced by farmers during postharvest periods discourage many local yam farmers from considering large scale cultivation of the crop, which to a large extent threatens food security [6]. Yam spoilage is predominantly caused by fungus when the raw yam is exposed to attack during storage. Drying of yam is very important before storage, as it will help to reduce its size for ease of transportation, and to ensure its wholesomeness for a long period of time. Before drying, it is advisable for yam tubers to be peeled, sliced and blanched; and may be converted to floor after drying. Blanching helps to preserve colour and improves texture after drying. Blanching also improves drying rate, denatures enzymes, and destroys contaminants $[7,8]$.

Generally, the drying kinetics of food crops which are crop specific, are influenced by factors such as drying air temperature and velocity, pretreatment method, relative humidity, and product sizes [9, 10,11]. Many food crops need long drying times with optimum drying air temperatures requiring large quantity of energy that results in high overhead drying cost and high prices of dried food products [6]. Thus, agricultural products drying which involves the mechanism of heat and mass transfer requires an understanding of the drying kinetics of the products which may be useful in the design of dryers and the optimization of the drying process parameters. They are very important as they help in the quantitative evaluation of energy requirements and its losses in drying facilities $[12,13]$. These engineering properties which are crop specific include the effective moisture diffusivity, activation energy and specific energy consumption. Many researchers have studied the drying behaviour of some indigenous species of yam slices, but there has not been any consideration of their energy consumption in conventional drying systems. Hence, this work was aimed at studying the energy consumption of blanched yam samples in a convective hot air waste heat recovery dryer.

\section{Materials and Methods}

\subsection{Preparation of sample and drying procedure}

White yam tubers (Dioscorea rotundata) were procured from the popular Relief Market in Owerri municipal of Imo State, Nigeria. The samples were prepared by washing, peeling and slicing with a kitchen knife; blanching with water at $80^{\circ} \mathrm{C}$ for a period of 30 minutes; dewatering of the blanched samples; and finally storing them in a refrigerator at $4{ }^{\circ} \mathrm{C}$. The study was conducted using an exhaust gas waste heat recovery tray dryer whose schematic representation is as shown in Fig. 1. The dryer was designed and developed by Ononogbo et al. [6] at Imo State Polytechnic, Umuagwo in Imo State, Nigeria. The drying equipment uses the exhaust gas waste heat of a stationary electric generator to heat up the ambient air for drying purposes. The yam samples for the experimental investigation were sliced into three different thicknesses of 1.0 $\mathrm{cm}, 1.5 \mathrm{~cm}$, and $2.0 \mathrm{~cm}$, respectively. For each batch of the drying experiments, $2200 \mathrm{~g}$ of the preserved samples initially at a moisture content of $69.5 \%$ were dried to a moisture content of $12 \%$ (wet basis). The experimental investigations were carried out at varying conditions of drying air temperatures and velocities of 55,65 , and $75^{\circ} \mathrm{C}$; and $1.0,1.5$, and $2.0 \mathrm{~m} / \mathrm{s}$, respectively. During each batch of the drying experiments, weight losses of the samples were recorded at 20 minutes intervals with an MLC 825-China weight sensor of accuracy: \pm $0.05 \mathrm{~g}$. Temperature sensors were attached to the drying tray and outside the dryer in order to record the temperatures of the drying air at the selected drying tray, and the ambient air temperature. The speed of the drying air for each drying condition was regulated by a suitable configuration of an anemometer, an air blower with the control panel during the process of drying.

\subsection{The electric power consumption during the drying} process

The total electric power consumed per drying batch, $P_{t}(\mathrm{~W}-\mathrm{hr})$ can be obtained as the product of the total electric power output of the dryer $\left(P_{\text {outd }}\right)$ and the total drying time $\left(d_{t}\right)$. Hence,

$$
P_{t}=d_{t} \times P_{\text {outd }}
$$

\subsection{Determination of the specific power consumption}

The specific power consumption, $P_{s c}(\mathrm{~W}-\mathrm{hr} / \mathrm{kg})$ as expressed by Motevali and Chayian [14], is the ratio of the total electric power consumption to the mass of product sample to be dehydrated, $m_{w}(\mathrm{~kg})$. Thus,

$$
P_{s c}=\frac{P_{t}}{m_{w}}
$$

\subsection{Determination of the specific energy consumption}

The specific energy consumption, $\varepsilon(\mathrm{kW}-\mathrm{hr} / \mathrm{kg})$ for each drying batch is the ratio of the total energy consumption, $E_{T}(\mathrm{~kW}-\mathrm{hr})$ to the mass of moisture, $M_{w}(\mathrm{~kg})$ removed from the product sample $[13,15]$ :

$$
\varepsilon=\frac{E_{T}}{M_{w}}
$$

But

$$
E_{T}=E_{t h}+P_{t}
$$

The thermal energy required to execute drying, $E_{t h}(\mathrm{~kW}-\mathrm{hr})$, can be obtained using Eqn (5) [12, 13,15]:

$$
E_{t h}=\left(v_{a} A_{t} \rho_{a} c_{a} \Delta T\right) d_{t}
$$




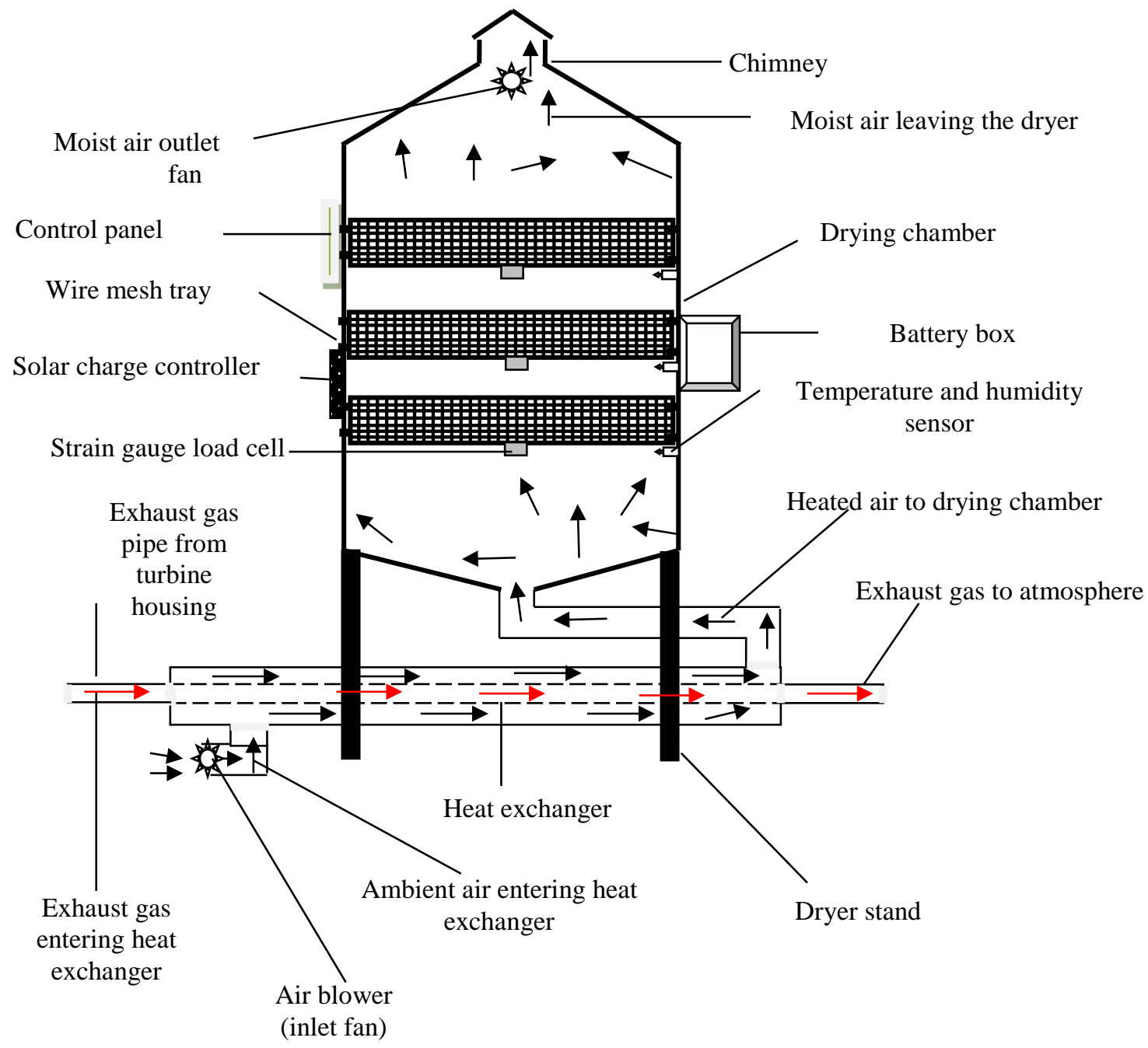

Fig. 1. Schematic diagram of the exhaust gas heat recovery tray dryer

where $v_{a}, A_{t}, c_{a}$ and $\rho_{a}$ are the drying air speed $(\mathrm{m} / \mathrm{s})$, area of the drying tray $\left(\mathrm{m}^{2}\right)$, air specific heat capacity $(\mathrm{kJ} / \mathrm{kgK})$ and air density $\left(\mathrm{kg} / \mathrm{m}^{3}\right) . \Delta T$ is the difference in temperature $(\mathrm{K})$ between the ambient air and the hot drying air. $\rho_{a}$ can be calculated using Eqn (6) [16]:

$$
\rho_{a}=\frac{101.325}{0.287 T_{a}}
$$

whereas $c_{a}$ may be obtained using Eqn (7) [17]:

$$
c_{a}=1.04841-\frac{3.83719 T_{a}}{10^{4}}+\frac{9.45378 T_{a}{ }^{2}}{10^{7}}-\frac{5.49031 T_{a}{ }^{3}}{10^{10}}+\frac{7.92981 T_{a}{ }^{4}}{10^{14}}
$$

\section{RESULTS AND DISCUSSION}

\subsection{Effects of drying air temperature and velocity on the electric energy consumption during drying}

The energy of the battery expended during the period of each drying batch was used in the evaluation of the total electric power consumption $\left(P_{t}\right)$ as expressed in Eqn (1). This was obtained by finding the product of the total electric power output (for each velocity level) as shown in Table 2 and the corresponding total drying time for each batch as shown in Tables 3 to 5 . Table 2 
was obtained as the total sum of the output power values of the components of the drying equipment at the selected drying air velocities as shown in Table 1.

Table 1: Measured values of electric current flow through the components of the dryer during operation

\begin{tabular}{|c|c|c|c|c|c|c|c|}
\hline $\mathbf{S} / \mathbf{N}$ & $\begin{array}{c}\text { Total } \\
\text { number }\end{array}$ & Device & Status & $\begin{array}{c}\text { Air } \\
\text { velocity } \\
\left(m s^{-1}\right)\end{array}$ & $\begin{array}{c}\text { Current } \\
\text { flow } \\
(\mathbf{m A})\end{array}$ & $\begin{array}{c}\text { Rated } \\
\text { voltage } \\
\text { (V) }\end{array}$ & $\begin{array}{c}\text { Power output } \\
\text { (W) }\end{array}$ \\
\hline \multirow{3}{*}{1} & \multirow{3}{*}{1} & \multirow{3}{*}{ Air blower } & \multirow{3}{*}{ Varying } & 1.0 & 480 & \multirow{3}{*}{12} & 5.76 \\
\hline & & & & 1.5 & 620 & & 7.44 \\
\hline & & & & 2.0 & 810 & & 9.72 \\
\hline \multirow{3}{*}{2} & \multirow{3}{*}{1} & \multirow{3}{*}{ Outlet fan } & \multirow{3}{*}{ Constant } & 1.0 & 200 & \multirow{3}{*}{12} & 2.40 \\
\hline & & & & 1.5 & 200 & & 2.40 \\
\hline & & & & 2.0 & 200 & & 2.40 \\
\hline \multirow{3}{*}{3} & \multirow{3}{*}{6} & \multirow{3}{*}{$\begin{array}{l}\text { Temperature and } \\
\text { humidity sensor }\end{array}$} & \multirow{3}{*}{ Constant } & 1.0 & 20 & \multirow{3}{*}{5} & 0.60 \\
\hline & & & & 1.5 & 20 & & 0.60 \\
\hline & & & & 2.0 & 20 & & 0.60 \\
\hline \multirow{3}{*}{4} & \multirow{3}{*}{3} & \multirow{3}{*}{ Weight sensor } & \multirow{3}{*}{ Constant } & 1.0 & 30 & \multirow{3}{*}{5} & 0.45 \\
\hline & & & & 1.5 & 30 & & 0.45 \\
\hline & & & & 2.0 & 30 & & 0.45 \\
\hline \multirow{3}{*}{5} & \multirow{3}{*}{1} & \multirow{3}{*}{ Microcontroller } & \multirow{3}{*}{ Constant } & 1.0 & 80 & \multirow{3}{*}{5} & 0.40 \\
\hline & & & & 1.5 & 80 & & 0.40 \\
\hline & & & & 2.0 & 80 & & 0.40 \\
\hline \multirow{3}{*}{6} & \multirow{3}{*}{1} & \multirow{3}{*}{ LCD } & \multirow{3}{*}{ Constant } & 1.0 & 120 & \multirow{3}{*}{5} & 0.60 \\
\hline & & & & 1.5 & 120 & & 0.60 \\
\hline & & & & 2.0 & 120 & & 0.60 \\
\hline \multirow{3}{*}{7} & \multirow{3}{*}{1} & \multirow{3}{*}{$\begin{array}{l}\text { Other contents of } \\
\text { the control panel }\end{array}$} & \multirow{3}{*}{ Constant } & 1.0 & 100 & & 0.50 \\
\hline & & & & 1.5 & 100 & 5 & 0.50 \\
\hline & & & & 2.0 & 100 & & 0.50 \\
\hline
\end{tabular}

Table 2: Total electric power output of the components of the dryer at various air velocities

\begin{tabular}{cc}
\hline $\begin{array}{c}\text { Air velocity } \\
\left(\mathrm{m} \mathrm{s}^{-1}\right)\end{array}$ & $\begin{array}{c}\text { Electric Power Output } \\
(\mathbf{W})\end{array}$ \\
\hline $\mathbf{1 . 0}$ & 10.71 \\
$\mathbf{1 . 5}$ & 12.39 \\
$\mathbf{2 . 0}$ & 14.67 \\
\hline
\end{tabular}

The minimum value of $P_{t}(44.63 \mathrm{~W}-\mathrm{hr})$ was achieved at the drying air temperature and velocity of $75^{\circ} \mathrm{C}, 1.0 \mathrm{~m} / \mathrm{s}$ and $1.0 \mathrm{~cm}$ slice thickness; whereas a maximum value of $157.70 \mathrm{~W}$ hr was obtained at the drying air temperature and velocity of $55^{\circ} \mathrm{C}, 2.0 \mathrm{~m} / \mathrm{s}$ and $2.0 \mathrm{~cm}$ slice thickness, respectively. $P_{t}$ values ranged from 44.63 to $128.36 \mathrm{~W}$-hr, 58.01 to $143.03 \mathrm{~W}$ $\mathrm{hr}$ and 65.15 to $157.70 \mathrm{~W}-\mathrm{hr}$, respectively for $1.0 \mathrm{~cm}, 1.5 \mathrm{~cm}$ and $2.0 \mathrm{~cm}$ slice thicknesses as shown in Tables 3 to 5. A similar trend was reported by Beigi [12], where the minimum energy consumption was obtained at the highest air temperature of 70 ${ }^{\circ} \mathrm{C}$ and lowest air velocity of $1.0 \mathrm{~m} / \mathrm{s}$ treatment; whereas the maximum energy consumption was achieved at the lowest air temperature of $55{ }^{\circ} \mathrm{C}$ and highest air velocity of $2.0 \mathrm{~m} / \mathrm{s}$ treatment for the drying of apple slices. This shows that lower drying air temperatures take longer times for the completion of a drying batch resulting in more consumption of electrical energy. On the other hand, increasing the drying air temperature causes a reduction in the drying time of products, and hence a decrease in the energy consumption. However, from Tables 3 to 5 , it can be easily seen that at each of the drying air temperatures, $P_{t}$ values increased with an increase in the drying air speed. This may be as a result of the fact that higher air speeds need more energy to operate the air blower and other electrical components of the dryer. Whereas at each drying air speed, the electric energy consumed decreased with an increase in the drying air temperature. This observation is in agreement with the report given by Abbaszadeh et al. [18] in terms of energy consumption for the dehydration of Russian olives. Furthermore, it is obvious from Tables 3 to 5, that the higher the slice thickness, the higher the values of $P_{t}$.

\subsection{The specific power consumption}

The specific power consumption $\left(P_{s c}\right)$ was calculated using Eqn (2). Figures 2 to 4 show the relationship between 
specific power consumption, drying air temperature and velocity for the yam slice drying. The minimum values obtained were $20.29,26.37$ and $29.61 \mathrm{~W}-\mathrm{hr} / \mathrm{kg}$ for the $1.0,1.5$ and $2.0 \mathrm{~cm}$ slice thicknesses, respectively. These values represent the minimum electrical power needed for the drying of $1 \mathrm{~kg}$ of the blanched yam samples at the highest drying air temperature and lowest drying air velocity $\left(75^{\circ} \mathrm{C}\right.$ and $\left.1.0 \mathrm{~m} / \mathrm{s}\right)$. The maximum values of $P_{S C}$ obtained were $58.35,65.01$ and $71.68 \mathrm{~W}-\mathrm{hr} / \mathrm{kg}$, respectively for the $1.0,1.5$ and $2.0 \mathrm{~cm}$ yam slice thicknesses. These values were achieved at the lowest drying air temperature and highest drying air velocity $\left(55^{\circ} \mathrm{C}\right.$ and $\left.2.0 \mathrm{~m} / \mathrm{s}\right)$ of the product samples. From these tables, it can .also be observed that the higher the slice thickness, the higher the values of $P_{S C}$ obtained.

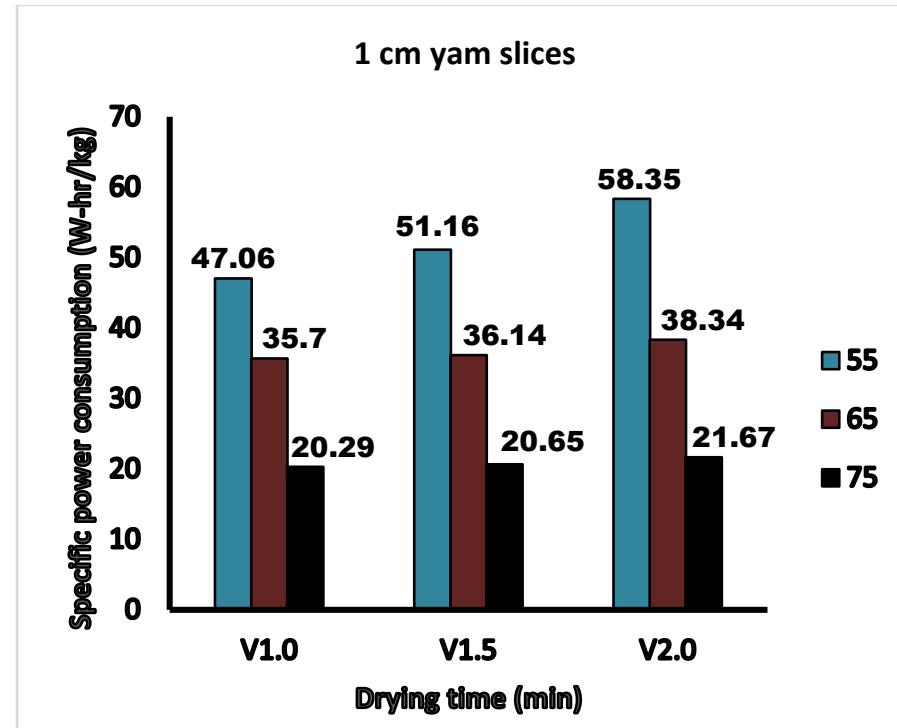

Fig. 2. $P_{s c}$ for $1 \mathrm{~cm}$ yam slice drying at varying air temperatures and velocities

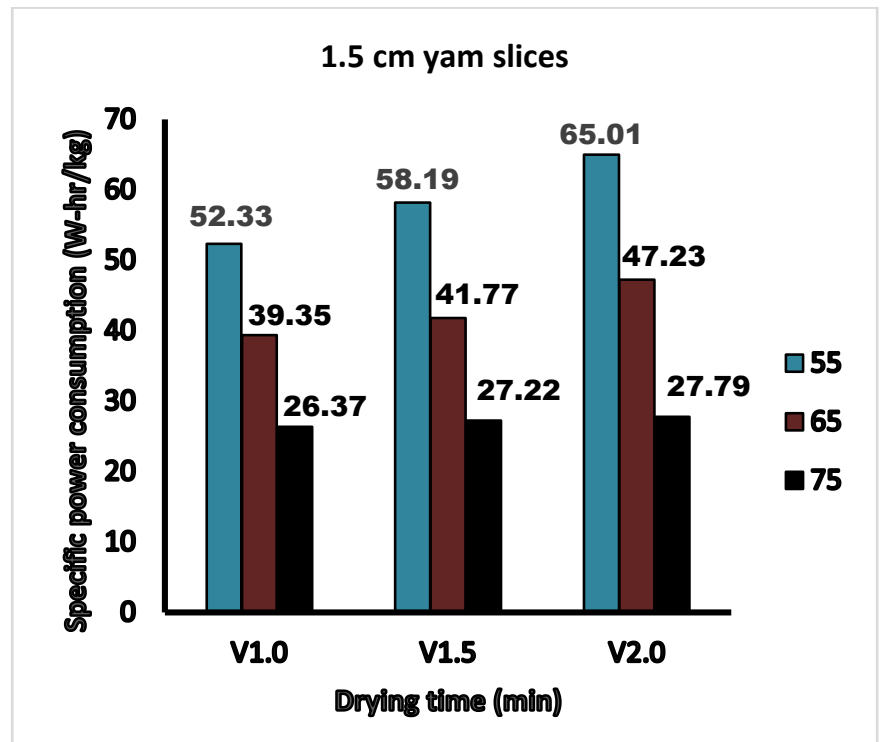

Fig. 3. $P_{s c}$ for $1.5 \mathrm{~cm}$ yam slice drying at varying air temperatures and velocities

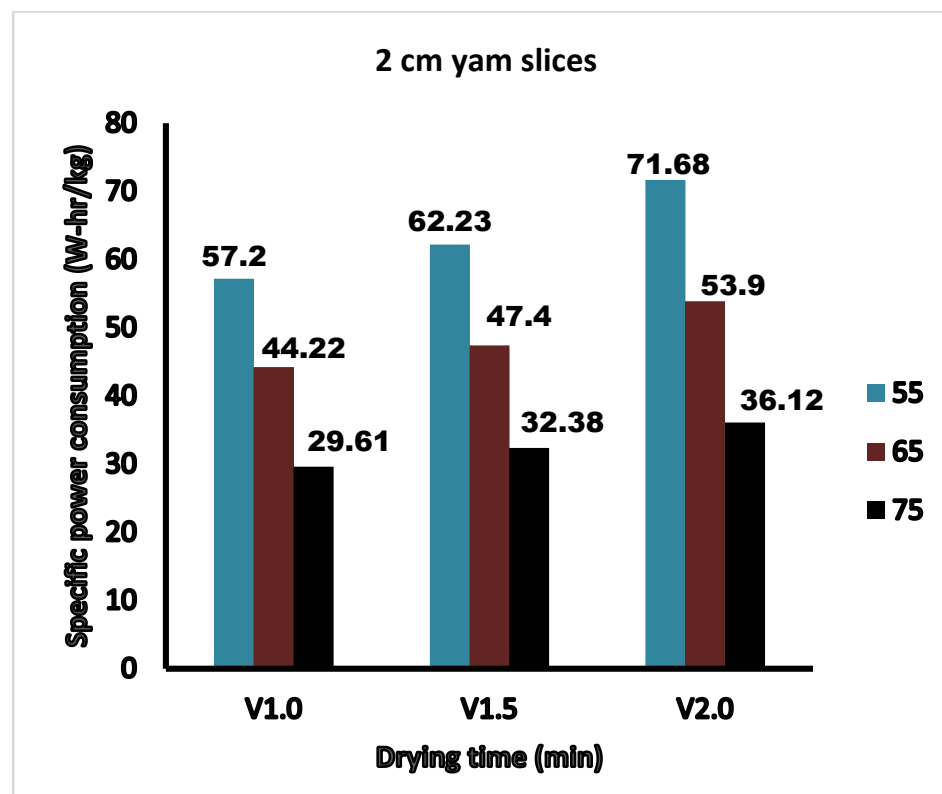

Fig. 4. $P_{s c}$ for $2 \mathrm{~cm}$ yam slice drying at varying air temperatures and velocities

\subsection{Thermal energy consumption during drying of the products}

The thermal energy consumed, $E_{t h}(\mathrm{~kW}-\mathrm{hr})$ during the drying of the samples was calculated using Eqn (5). From Tables 3 to 5, it could be clearly seen that the values of the minimum $E_{t h}$ obtained followed the same trend as the recorded minimum values of $P_{t}$, in the sense that the minimum values $(57.88,75.19$ and $84.44 \mathrm{~kW}-\mathrm{hr}$ for $1.0,1.5$ and $2 \mathrm{~cm}$ ) were achieved at the maximum temperature $\left(75^{\circ} \mathrm{C}\right)$ and minimum velocity $(1.0 \mathrm{~m} / \mathrm{s})$. However, the maximum values of $E_{t h}$ obtained $(140.64,156.57$ and 178.42 $\mathrm{kW}$-hr, for the 1.0, 1.5 and $2 \mathrm{~cm}$ yam slices), did not follow a clear and exact pattern of arrangement. This is because the maximum values obtained for both $1.0 \mathrm{~cm}$ and $1.5 \mathrm{~cm}$ yam slices (which are in line with the foregoing trend) occurred at the minimum air temperature $\left(55^{\circ} \mathrm{C}\right)$ and maximum air velocity $(2.0 \mathrm{~m} / \mathrm{s})$ as shown in Tables 3 to 4 . Whereas the maximum value of $E_{t h}$ for the $2 \mathrm{~cm}$ yam slices (178.42) occurred at $65^{\circ} \mathrm{C}$ as shown in Table 5. In addition, it is noticeable from Tables 3 to 5 that the electric energy 
consumed is negligible in comparison to the corresponding thermal energy consumed. This is as a result of the fact that for drying systems using hot air stream for products drying, the major portion of the energy is used in the heating of the drying air.

3.4. Total and specific energy consumption during drying of the products

The total energy consumed during the drying process, $E_{T}(\mathrm{~kW}-$ hr) is equivalent to the sum of $E_{t h}$ and $P_{t}$ as shown in Eqn (4). The recorded $E_{T}$ values as tabulated in Tables 3 to 5 were in the range of 57.88 to $140.64,75.25$ to 156.71 and 84.51 to 178.54
$\mathrm{kW}-\mathrm{hr}$, respectively for $1.0,1.5$ and $2.0 \mathrm{~cm}$ slice thicknesses. The specific energy consumption, $\varepsilon(\mathrm{kW}-\mathrm{hr} / \mathrm{kg})$ was obtained using Eqn (3), and the values are as shown in Tables 3 to 5. Thus, $\varepsilon$ values were in the range of 40.25 to $97.80,52.33$ to 108.79 and 58.77 to $124.16 \mathrm{~kW}-\mathrm{hr} / \mathrm{kg}$, respectively for $1.0,1.5$ and $2.0 \mathrm{~cm}$ slice thicknesses.

Table 3: Energy parameters for yam slices of $1 \mathrm{~cm}$ at different drying air temperatures and velocities

\begin{tabular}{|c|c|c|c|c|c|c|c|}
\hline $\begin{array}{c}\mathrm{T} \\
\left({ }^{\circ} \mathrm{C}\right)\end{array}$ & $\begin{array}{c}\mathrm{V} \\
(\mathbf{m} / \boldsymbol{s})\end{array}$ & $\begin{array}{c}\boldsymbol{d}_{\boldsymbol{t}} \\
(\mathrm{min})\end{array}$ & $\begin{array}{c}\boldsymbol{P}_{\boldsymbol{t}} \\
(\mathrm{W}-\mathrm{hr})\end{array}$ & $\begin{array}{c}\boldsymbol{P}_{\boldsymbol{s c}} \\
(\mathrm{W}-\mathrm{hr} / \mathrm{kg})\end{array}$ & $\begin{array}{c}\boldsymbol{E}_{\boldsymbol{t h}} \\
(\mathrm{kW}-\mathrm{hr})\end{array}$ & $\boldsymbol{E}_{\boldsymbol{t}}(\mathrm{kW}-\mathrm{hr})$ & $\begin{array}{c}\boldsymbol{\varepsilon} \\
(\mathrm{kW}-\mathrm{hr} / \mathrm{kg})\end{array}$ \\
\hline \multirow{3}{*}{$\mathbf{5 5}$} & 1.0 & 580 & 103.53 & 47.06 & 77.62 & 77.72 & 54.05 \\
& 1.5 & 545 & 112.54 & 51.16 & 109.39 & 109.51 & 76.15 \\
& 2.0 & 525 & 128.36 & 58.35 & 140.51 & 140.64 & 97.80 \\
\hline \multirow{3}{*}{$\mathbf{6 5}$} & 1.0 & 440 & 78.54 & 35.70 & 80.93 & 81.01 & 56.34 \\
& 1.5 & 385 & 79.50 & 36.14 & 106.22 & 106.30 & 73.92 \\
& 2.0 & 345 & 84.35 & 38.34 & 126.92 & 127.00 & 88.32 \\
\hline \multirow{3}{*}{$\mathbf{7 5}$} & 1.0 & 250 & 44.63 & 20.29 & 57.84 & 57.88 & 40.25 \\
& 1.5 & 220 & 45.43 & 20.65 & 76.35 & 76.39 & 53.12 \\
& 2.0 & 195 & 47.68 & 21.67 & 90.22 & 90.28 & 62.78 \\
\hline
\end{tabular}

Table 4: Energy parameters for yam slices of $1.5 \mathrm{~cm}$ at different drying air temperatures and velocities

\begin{tabular}{|c|c|c|c|c|c|c|c|}
\hline $\begin{array}{c}\mathrm{T} \\
\left({ }^{\circ} \mathrm{C}\right)\end{array}$ & $\mathrm{v}(\mathbf{m} / \boldsymbol{s})$ & $\boldsymbol{d}_{\boldsymbol{t}}(\mathrm{min})$ & $\begin{array}{c}\boldsymbol{P}_{\boldsymbol{t}} \\
(\mathrm{W}-\mathrm{hr})\end{array}$ & $\begin{array}{c}\boldsymbol{P}_{\boldsymbol{s c}} \\
(\mathrm{W}-\mathrm{hr} / \mathrm{kg})\end{array}$ & $\begin{array}{c}\boldsymbol{E}_{\boldsymbol{t h}} \\
(\mathrm{kW}-\mathrm{hr})\end{array}$ & $\boldsymbol{E}_{\boldsymbol{t}}(\mathrm{kW}-\mathrm{hr})$ & $\begin{array}{c}\boldsymbol{\varepsilon} \\
(\mathrm{kW}-\mathrm{hr} / \mathrm{kg})\end{array}$ \\
\hline \multirow{3}{*}{55} & 1.0 & 645 & 115.13 & 52.33 & 86.31 & 86.43 & 60.10 \\
& 1.5 & 620 & 128.03 & 58.19 & 124.45 & 124.58 & 86.63 \\
& 2.0 & 585 & 143.03 & 65.01 & 156.57 & 156.71 & 108.98 \\
\hline \multirow{3}{*}{65} & 1.0 & 485 & 86.57 & 39.35 & 89.21 & 89.29 & 62.09 \\
& 1.5 & 445 & 91.89 & 41.77 & 122.78 & 122.87 & 85.45 \\
& 2.0 & 425 & 103.91 & 47.23 & 156.35 & 156.45 & 108.79 \\
\hline \multirow{3}{*}{75} & 1.0 & 325 & 58.01 & 26.37 & 75.19 & 75.25 & 52.33 \\
& 1.5 & 290 & 59.89 & 27.22 & 100.64 & 100.69 & 70.03 \\
& 2.0 & 250 & 61.13 & 27.79 & 115.68 & 115.74 & 80.49 \\
\hline
\end{tabular}

Table 5: Energy parameters for yam slices of $2 \mathrm{~cm}$ at different drying air temperatures and velocities

\begin{tabular}{|c|c|c|c|c|c|c|c|}
\hline $\begin{array}{c}\mathrm{T} \\
\left({ }^{\circ} \mathrm{C}\right)\end{array}$ & $\begin{array}{c}\mathrm{v}(\mathbf{m} / \\
\boldsymbol{s})\end{array}$ & $\boldsymbol{d}_{\boldsymbol{t}}(\min )$ & $\begin{array}{c}\boldsymbol{P}_{\boldsymbol{t}} \\
(\mathrm{W}-\mathrm{hr})\end{array}$ & $\begin{array}{c}\boldsymbol{P}_{\boldsymbol{s c}} \\
(\mathrm{W}-\mathrm{hr} / \mathrm{kg})\end{array}$ & $\begin{array}{c}\boldsymbol{E}_{\boldsymbol{t h}} \\
(\mathrm{kW}-\mathrm{hr})\end{array}$ & $\boldsymbol{E}_{\boldsymbol{t}}(\mathrm{kW}-\mathrm{hr})$ & $\begin{array}{c}\boldsymbol{\varepsilon} \\
(\mathrm{kW}-\mathrm{hr} / \mathrm{kg})\end{array}$ \\
\hline \multirow{3}{*}{55} & 1.0 & 705 & 125.84 & 57.20 & 94.34 & 94.47 & 65.69 \\
\hline & 1.5 & 665 & 136.91 & 62.23 & 133.48 & 133.62 & 92.92 \\
\hline & 2.0 & 645 & 157.70 & 71.68 & 172.63 & 172.78 & 120.16 \\
\hline \multirow{3}{*}{65} & 1.0 & 545 & 97.28 & 44.22 & 100.25 & 100.34 & 69.78 \\
\hline & 1.5 & 505 & 104.28 & 47.40 & 139.33 & 139.44 & 96.97 \\
\hline & 2.0 & 485 & 118.58 & 53.90 & 178.42 & 178.54 & 124.16 \\
\hline \multirow{3}{*}{75} & 1.0 & 365 & 65.15 & 29.61 & 84.44 & 84.51 & 58.77 \\
\hline & 1.5 & 345 & 71.24 & 32.38 & 119.75 & 119.79 & 83.31 \\
\hline & 2.0 & 325 & 79.46 & 36.12 & 150.38 & 150.46 & 104.63 \\
\hline
\end{tabular}

\section{Conclusion}

The investigation of the energy consumption of yam slice drying was successfully conducted in this study. The overall results showed noticeable effects of the drying air temperature and velocity on the energy consumption values of the dryer during the drying of the sample product. It is obvious from the results that the higher the drying air temperature, the lower the energy consumption. Conversely, the higher the drying air velocity, the higher the value of the energy consumption. It was also observed that for all the experimental treatments, the higher the slice thickness of the yam samples, the higher the obtained energy consumption values. Thus, the maximum energy consumption values for all the response energy variables were recorded at the $2 \mathrm{~cm}$ slice thickness. Whereas the minimum energy consumption values for all the energy 
variables were recorded at the $1 \mathrm{~cm}$ slice thickness. This shows that to minimize energy consumption during products drying, it is important to reasonably reduce the thickness of the product to be dried, maximize the drying air temperature, and minimize the drying air velocity.

\section{References}

[1] F. Nweke, R. Aidoo, \& B. Okoye, "Yam Consumption Patterns in West Africa., Final Report for Bill \& Melinda Gates Foundation (BMGF)," July 2013.

[2] A. A. Akinola and S. N. Ezeorah, "Moisture Diffusivity and Activation Energy Estimation of White Yam (Dioscorea rotundata) Slices Using Drying Data from a Refractance WindowTM Dryer," FUOYE Journal of Engineering and Technology, Vol. 4, pp. 102-106, Issue 1, March 2019 ISSN: 2579-0625 (Online), 2579-0617 (Paper)

[3] D. J., Yang and J. T. Lin, "Effects of different storage conditions on steroidal saponins in yam (Dioscorea pseudojaponica Yamamoto) tubers," Food Chem., Vol. 110, pp. 670-67, 2008.

[4] H. W., Xiao, X. D., Yao, H. Lin, W. X. Yang, J. S. Meng, and Z. J. Gao, "EFFECT of SSB (superheated steam blanching) time and drying temperature on hot air impingement drying kinetics and quality attributes of yam slices," J. Food Process Eng., Vol. 35, pp. 370-390, 2012.

[5] MOFA, "Statistics, Research and Information Directorate (SRID)," 2007.

[6] C. Ononogbo, O.C. Nwufo, C.A. Okoronkwo, N.V. Ogueke, J.O. Igbokwe, E.E. Anyanwu, "Equipment sizing and method for the application of exhaust gas waste heat to food crops drying using a hot air tray dryer," Indian Journal of Science and Technology, Vol. 13, pp. 502-518, 2020, DOI: 10.17485/ijst/2020/ v013i05/145593.

[7] N. Therdthai and W. Zhou, "Mathematical modelling of solar drying of apricot in thin layers," J. Food Eng. Vol. 91, pp. 482-489, 2009.

[8] S. Abasi, S. Minaei, M. H. Khoshtaghaza, "Effect of the desiccant system on thin-layer drying kinetics of corn. Journal of Food Science and Technology," 2017, DOI 10.1007/s13197017-2914-z.
[9] B.I.O. Ade-Omowaye, N.K. Rastogi, A. Angersbach, D. Knorr, "Osmotic dehydration behaviour of red paprika (Capsicum annuum 400 L.)," Journal of Food Science, Vol. 67, pp. 1790-1796, 2002.

[10] T. Kudra, "Energy aspects in drying, "Drying Technology," Vol. 22, pp. 917-932, 2004.

[11] R.E. Sanful, A. Addo, I. Oduro, W.O. Ellis, "Air drying characteristics of aerial Yam (Dioscorea bulbifera)," Sch. J. Eng. Tech., Vol. 3, pp. 693-700, 2015.

[12] M. Beigi, Energy efficiency and moisture diffusivity of apple slices during convective drying. Food Sci. Technol. 36(1), 145-150 (2016) DOI: 10.1590/1678-457X.0068.

[13] C. E. Onu, P.K. Igbokwe, J. T. Nwabanne, "Effective moisture diffusivity, activation energy and specific energy consumption in the thin-layer drying of potato," International Journal of Novel Research in Engineering and Science, Vol. 3, pp. 10-22, 2017.

[15] N.R. Nwakuba, O.C. Chukwuezie, G.U. Asonye, S.N. Asoegwu, "Influence of process parameters on the energy requirements and dried sliced tomato quality," Engineering Reports, 2020, e12123, https://doi.ogr/10.1002/eng2.12123.

[16] Z. Naghavi, A. Moheb, S. Ziaei-Rad, Numerical simulation of rough rice drying in a deep-bed dryer using the nonequilibrium model, Energy Conversion and Management, Vol. 51, pp. 258-264, 2009.

[17] M. Aghbashlo, M. H. Kianmehr, H. Samimi-Akhijahani, "Influence of drying conditions on the effective moisture diffusivity, energy of activation and energy consumption during the thin-layer drying of beriberi fruit (Beriberidaceae), "Energy Conversion and Management," Vol. 49, pp. 2865-2871, 2008.

[18] A. Abbaszadeh, A. Motevali, B. Ghobadian, M.H. Khoshtaghaza, S. Minaei, "Effect of air velocity and temperature on energy and effective moisture diffusivity for Russian olive (Elaeugnusan gastifolial) in thin-layer drying," Iran Journal of chemistry and chemical engineering, Vol. 3, pp. $175-79,2012$. 